For citation: Demidova, O. A., Daddi, P., Medvedeva, E. V. \& Signorelli, M. (2018). Modeling the Employment Rate in Russia: a Spatial-Econometric Approach. Ekonomika Regiona [Economy of Region], 14(4), 1383-1398

doi 10.17059/2018-4-25

UDC: 331

O. A. Demidova ${ }^{a}$, P. Daddi ${ }^{b}$, E. V. Medvedeva ${ }^{c}$, M. Signorelli ${ }^{\text {) }}$

a) National Research University Higher School of Economics (Moscow, Russian Federation; e-mail: demidova@hse.ru)

b) University of Perugia, Department of Economics (Perugia, Italy)

c) PJSC "Post Bank" (Moscow, Russian Federation)

\title{
MODELING THE EMPLOYMENT RATE IN RUSSIA: A SPATIAL-ECONOMETRIC APPROACH
}

The purpose of this study is to identify factors that affect the level of employment in Russian regions. However, Russia is not a homogeneous country, and this effect may not be the same for all regions. That is why we split the regions of Russia into three groups, depending on the state of the labor market in this and neighboring regions. The HH (high-high) group comprises regions with a favorable situation in their labor markets, and which are also surrounded mostly by prosperous regions. Two groups of regions with a less favorable situation are located respectively in the south of Russia (LL1, low-low group 1) and southern Siberia and Zabaikalye (LL2, low-low group 2). We considered the twelve-year period from 2005 to 2016. As explanatory variables, we used variables for the attractiveness of the region, demographic characteristics of the region, and the degree of diversity of employees by economic activities. We tested hypotheses about differences in 1) the spatial effects and 2) the impact of the various explanatory variables for these groups of variables. To test our main hypotheses, we used spatial regression dynamic models estimated with the help of the generalized method of moments. Both main hypotheses received empirical confirmation. Spatial effects were different. The regions of the LL2 group are not affected by the situation in other local markets; regions of LL1 and HH groups are affected by the rest of Russia's regions, and the extent of this influence decreases with the increase in geographical distance between regions. Moreover, the regions of the LL1 group compete with neighboring regions: if the situation in one of them improves, then it draws on the resources of the others. Regarding the impact of the explanatory variables, the "group effect" was revealed for the variables: share of urban population, net migration rate, shares of people below and above working age, share of people with higher education. Our results can favor the better design of national and regional policies to improve labor market performance in Russia based on the heterogeneity of the Russian regions.

Keywords: employment, labor market, regional data, spatial effects, spatial models, labor policies, development policies

\section{Introduction}

The socio-economic development plan for the Russian Federation until 2020 states that the priorities of the state regional policy are (i) balanced socio-economic regional development, and (ii) the reduction of interregional disparities.

So, knowing how regions are distributed into high or low employment groups/clusters is a key empirical issue with significant policy implications. However, according to [1] Oschepkov and Kapelyushnikov (2015), there is no single joint Russian labor market; instead, there is a system of rather weak interrelated territorial/local labor markets. The reasons are mainly the low mobility of the Russian population and significant differences among regions located in different parts of Russia. The authors also note that there are

${ }^{1}$ (c) Demidova O. A., Daddi P., Medvedeva E. V., Signorelli M. Text. 2018 two groups of regions that were quite stable in the time interval 2000-2014: "leaders" (with high employment, low unemployment, and high wages) and "outsiders" (with low employment, high unemployment, and low wages).

In our research, we sought to determine, by means of a dynamic spatial econometric approach, which factors affect one of the most important indicators of labor markets: the level of employment of the population. The focus was on the mutual influence of regions on each other. If we did not take account of such influence in the models used, we might have encountered the problem of shifting estimates due to the omission of an essential variable. At the same time, it was difficult to take account of the influence of regions on each other; in this case, the number of model parameters that would have to be estimated would exceed the number of observations. However, there are spatial-econometric models that enable the use of 
several parameters to take the mutual influence of regions into account.

In the next section, we provide a brief overview of the key theoretical aspects and the main literature on regional aspects of the Russian labor market. In the third section, we describe the distinction of Russian regions into groups using Moran plots and the "leader-outsider" approach, present our data sources, discuss the choice of explanatory variables, and state the main research hypotheses. In the fourth section, we describe the methodology of econometric modeling. The sixth section sets out the results of the estimation and their interpretation. The last section contains some concluding remarks and policy implications.

\section{The Theoretical Aspects and Literature Review}

An original feature of this paper is its use of the employment rate and not the more traditional unemployment rate indicator. Here we briefly provide a short theoretical explanation for this choice.

Although the unemployment rate is still adopted in both theoretical and empirical studies, a growing number of economists have shown the key importance of the employment rate and its relative advantages with respect to the unemployment rate, especially because of the difficulties with this latter indicator in clearly defining the "active search for a job" as the crucial feature distinguishing unemployed people from inactive ones. In addition, some international institutions have started to define key policy objectives in terms of employment rates; the main example is the European Union that, within the framework of the European Employment Strategy, in 2000 at the Lisbon Council defined total and female employment rates as the labor market's performance objectives, and a similar employment rate index has been confirmed with the "Europe 2020" strategy launched in 2010.

It should be stressed that the level and dynamic of the employment rate cannot be simply derived from the level and dynamic of the unemployment rate. Let us consider the relationship between the two labor market performance indicators. First, we define the unemployment rate $(U R)$ as the percentage ratio between the number of unemployed person $U$ (i.e. unemployed people actively searching for a job) and the labor force $L F$ (i.e. employed plus unemployed persons); second, we define the employment rate $(E R)$ as the percentage ratio between the employed persons $(E)$ and the working age population $P_{15-72}$; third, we define the participation rate $(P R)$ as the percentage ratio between labor force $(L F)$ and the working age population $P_{15-72}$.

$$
\begin{gathered}
U R=\frac{U \times 100}{L F}, \\
E R=\frac{E \times 100}{P_{15-72}}, \\
P R=\frac{L F \times 100}{P_{15-72}} .
\end{gathered}
$$

Starting from equations (1), (2) and (3), the employment rate can be redefined as the complement to one of the unemployment rate (divided by 100) multiplied by the participation rate:

$$
\begin{gathered}
E R=\frac{E \times 100}{P_{15-72}}=\frac{L F-U}{L F} \times \frac{L F \times 100}{P_{15-72}}= \\
=\left(1-\frac{U R}{100}\right) \times P R .
\end{gathered}
$$

From equation (4), we can derive the unemployment rate $(U R)$ as the complement to one of the ratios between employment rate $(E R)$ and participation rate $(P R)$ (the result multiplied by 100$)$.

$$
U R=\left(1-\frac{E R}{P R}\right) \times 100 \text {. }
$$

Considering equation (5), a complex relationship emerges between the unemployment and employment rates; in fact, for example, a reduction in the unemployment rate is compatible with a reduction in the employment rate if the absolute value of this latter is lower than the absolute value of the reduction in the participation rate. Hence, it is not surprising that the unemployment rate can have different dynamics over time with respect to the employment rate.

For the reasons above mentioned, we adopted the employment rate as the key indicator of labor market performance in our study applied to Russian regions.

A growing body of literature investigates labor market performance at regional (sub-national) level, especially in large countries. In particular, the mutual influence of regions on each other in modeling the unemployment rates of regions in one or several countries is more often taken into account with the help of spatial-econometric models ([2] Caroleo and Pastore, 2010; [3] Mussida and Pastore, 2015, [4] Dolton et al., 2015; [5] Vega and Elhorst, 2016; [6] Manning and Petrongolo, 2017). There are several studies on the European regions, like [7] Head and Thierry (2006), [8] Ketterer and Rodríguez-Pose (2016). Some authors note the heterogeneity of the labor market and often identify clusters of regions, or they use 'core-periph- 
ery' models. However, there are fewer papers devoted to the regional labor market in transition countries. A review can be found in [9] Huber (2007) and [10] Bah and Brada (2014). Russia is an example of such a country.

According to [3] Pastore and Missuda (2015, introduction), "the Russian case seems to be specific and interesting not only among other transition countries but also in the European perspective”. [11] Vakulenko and Gurvich (2016) highlight that "high wage flexibility is an important salient feature of the Russian labor market”; [12] Kapelyushnikov et al. (2012) argue that the current model of labor relations in Russia is a combination of very formal rules embodied in the Labor Code and a great variety of informal arrangements that make it feasible to relax those rules. This is a substantially flexible system.

In the case of Russia, from a regional perspective, issues related to economic growth have been studied more extensively ([13] Solanko, 2008; [14] Ledyaeva et al., 2008, [15] Kholodilin et al., 2012; [16] Akhmedjonov et al., 2013; [17] Lehmann and Silvagni, 2013; [18] Dolinskaya, 2002).

Almost all the available studies on regional labor markets examine unemployment rates ([19] Demidova and Signorelli, 2012, [20] Demidova et al., 2013, [21] Demidova et al., 2015, [22] Blinova et al., 2015, [23] Blinova et al., 2016, [24] Rusanovskiy and Markov, 2016). Hence, there is a lack of studies modeling regional employment rates. The exception is the work of [1] Oschepkov and Kapelyushnikov (2015) mentioned above, in which the authors come to the following conclusions: (i) regional labor markets in Russia converge; (ii) both regions-"leaders" and regions-"outsiders" tend to form clusters of nearby or adjacent regions. Thus, it makes sense to try to identify such clusters. [25] Danilenko et al. (2017) attempt to reveal clubs for the unemployment rate using Moran plots. In this paper, in addition to Moran plots, the "leader-outsider" approach was used ([1] Oschepkov and Kapelyushnikov (2015). Considering the above-discussed relationship between unemployment rate and employment rate it is not surprising that in this paper, we obtain empirical results different from those of other studies focused on unemployment rates (e.g., [25] Danilenko et al., 2017).

\section{Data and Variables}

\subsection{Data}

Our sample consisted of 80 regions during the twelve-year period from 2005 to 2016. The majority of the data used in the research were availa-
Table 1

United subjects of the Russian Federation

\begin{tabular}{|c|c|c|}
\hline Data & Merging regions & Incorporated as \\
\hline \multirow{3}{*}{01.01 .2007} & $\begin{array}{l}\text { Taymyr Autonomous } \\
\text { Okrug }\end{array}$ & \multirow{3}{*}{$\begin{array}{c}\text { Krasnoyarsk } \\
\text { Territory }\end{array}$} \\
\hline & $\begin{array}{l}\text { Evenk Autonomous } \\
\text { Okrug }\end{array}$ & \\
\hline & Krasnoyarsk territory & \\
\hline \multirow[b]{2}{*}{ 01.07.2007 } & Kamchatka oblast & \multirow{2}{*}{$\begin{array}{c}\text { Kamchatka } \\
\text { territory }\end{array}$} \\
\hline & $\begin{array}{l}\text { Koryak Autonomous } \\
\text { Okrug }\end{array}$ & \\
\hline \multirow[t]{2}{*}{01.01 .2008} & $\begin{array}{l}\text { Ust-Orda Buryat } \\
\text { Autonomous Okrug }\end{array}$ & \multirow[t]{2}{*}{ Irkutsk region } \\
\hline & Irkutsk region & \\
\hline \multirow[b]{2}{*}{01.03 .2008} & Chita region & \multirow{2}{*}{$\begin{array}{c}\text { Zabaykalsky } \\
\text { Territory }\end{array}$} \\
\hline & $\begin{array}{l}\text { Aginsky Buryatsky } \\
\text { Autonomous Okrug }\end{array}$ & \\
\hline 01.07 .2012 & Moscow, Moscow oblast & Moscow \\
\hline
\end{tabular}

ble for public access via the website of the Federal State Statistics Service (FSSS) of the Russian Federation. It was impossible to include earlier years in the research due to the different classification of industries before the year 2005 .

Moreover, data on some regions were missing (the Republic of Chechnya, the Republic of Crimea and Sevastopol). In addition, the Kaliningrad region was not included in the study because it has no common borders with other regions of Russia. Moreover, during the reporting period, some regions underwent changes of an administrative-territorial nature. This altering of boundaries was taken into consideration, mitigated by an aggregating procedure (see Table 1).

\subsection{The Splitting of Regions by Moran Plot}

Russian regions are not homogeneous, and employment levels differ considerably among them. We distinguish a group of regions with an employment level above the average and a group of regions with a level of employment below the average. It is also necessary to take account of the weighted average employment rate in neighboring regions (the weights are given by the weighted matrix $W$ matrix): it can also be above or below the average. Thus, we can distinguish four groups of regions. Traditionally used for such a division is the Moran chart, in which the horizontal axis states the standardized values of the employment rate $Z$, and the vertical axis states spatially weighted standardized values of the employment rate $W Z$.

In our analysis, a matrix of common borders was formed. It was represented by the following definition of $W$ : 


$$
W_{c b}=\left(\begin{array}{cccc}
0 & w_{12}^{l e n} & \ldots & w_{1 n}^{l e n} \\
w_{21}^{l e n} & 0 & \ldots & w_{2 n}^{l e n} \\
\vdots & \vdots & \ddots & \vdots \\
w_{n 1}^{l e n} & w_{n 2}^{l e n} & \ldots & 0
\end{array}\right),
$$

length in $\mathrm{km}$ of jont boundaries

$$
\begin{aligned}
& \text { where } w_{i j}^{\text {len }}=\frac{\text { between regions } i \text { and } j}{\text { total length in } \mathrm{km}} \text {. } \\
& \text { of all boundaries of region } i
\end{aligned}
$$

We used information on the length of joint boundaries taken from the State real estate cadastre. ${ }^{1}$ The matrix is line-normalized, so that $w_{i j}$ accounts for the weights of a region; $w_{i j}=0$, if there is no boundary between regions $i$ and $j$ or if $i=j$. For each region, we have a point on the Moran scatterplot which can be in one of four quarters. The first quarter represents the High-High group: this means that in the given region the employment rate is high and it is surrounded by regions also with high employment; it is a group of the most prosperous regions that positively influence each other. The second quarter represents the LowHigh group: the employment rate in the region is low, but the neighbor region has a high level of employment; this is a group of disadvantaged regions that can receive some benefits from proximity to prosperous regions. The third quarter represents the Low-Low group: both the region and neighbors have low employment rates; this group comprises the most disadvantaged regions. The fourth quarter represents the High-Low group: the employment rate is high for the region and low for its neighbors; this is a group of prosperous regions, but the situation in them may worsen due to proximity to unfavorable regions.

We thus obtained scatterplots for each year from 2005 to $2016 .{ }^{2}$ Each point was labeled by the number of the corresponding region. To determine the list of regions for each group, we counted how many times the corresponding points were in each quarter. We obtained the results set out in the table below.

It should be stressed that these groups of regions are close to, but not identical with, the group of four unemployment groups of regions in Russia discussed in [25] Danilenko et. al (2017).

In both cases, regions of LL group for employment and $\mathrm{HH}$ group for unemployment are geographically split into two parts: South of Russia and South of Siberia. We consequently decided to separate the $L L$ (employment) group into two

\footnotetext{
${ }^{1}$ For the Sakhalin region these boundaries are measured by sea. ${ }^{2}$ Available upon request.
}

groups. Additionally, $H L$ and $L H$ groups contain, respectively, only 5 and 11 regions. We decided to add those regions to larger groups; to determine the destination group, we used the "leader-outsider" approach followed by [1] Oschepkov and Kapelyushnikov (2015, the details are in the next section).

\subsection{The "Leader-Outsider" Approach}

[1] Oschepkov and Kapelyushnikov (2015) concluded that regions had stable positions in time on all indicators considered. They distinguished between "leader" and "outsider" regions. High employment and purchasing power of nominal wages together with a low unemployment rate are observed in leading regions. By contrast, high unemployment and a low level of economic activity characterize "outsider" regions. The same authors highlight that it is possible to allocate leading and lagging regions to clusters by geographic location. In their analysis, the authors discussed only the first and last ten regions (leaders and outsiders). Moreover, they did not give the exact list of regions for each indicator.

Following the same approach of [1] Oschepkov and Kapelyushnikov (2015), we made a list of regions for three indicators: employment rate, unemployment rate, and the purchasing power of nominal wages using rankings. We took the data on the employment rate from 2005 to 2016 for each region from Table 2 . Then, for each year, the regions were arranged in descending order by the employment rate and were ranked (the first region had rank 1, the second one rank 2 , and so on). In the final list, the regions were arranged in ascending order by the mean rank for 12 years (the smallest mean rank corresponded to the region with the highest employment rate). The result was the list of regions that follows.

It should be noted that the list of leaders is almost the same for all three indicators. If we now consider Table 1 again, we find that regions from $H H$ and $H L$ groups are at the top of the list in Table 2, while regions from $L L$ and $L H$ groups are at its bottom.

Finally, according to the Moran plot for employment rate and "leader-outsider approach", the Russian regions were divided into 3 final groups. $H L$ and $L H$ groups were attached to the corresponding groups $(H L+H H, L H+L L)$. The $L L$ group was split into two clubs: $L L 1$ group (South of Russia) and LL2 group (South of Siberia) by geographical criteria. Regions 40 and 54 were "outliers". To determine the relevant group, we calculated the mean value of the employment rate in those regions and clubs, and we joined "outliers" 
Table 2

List of employment groups

\begin{tabular}{|c|c|c|}
\hline HH (High-High) Regions & $L L$ (Low-Low) Regions & $L H$ (Low-High) Regions \\
\hline Vladimir region & Belgorod region & Bryansk region \\
\hline Ivanovo region & Voronezh region & Orel region \\
\hline Kaluga region & Kursk region & Ryazan region \\
\hline Kostroma region & Tambov region & Republic of Bashkortostan \\
\hline Smolensk region & Republic of Adygea & Penza region \\
\hline Tver region & Republic of Kalmykia & Ulyanovsk region \\
\hline Tula region & Krasnodar Territory & Kurgan region \\
\hline Yaroslavl region & Astrakhan region & Tomsk region \\
\hline Moscow & Volgograd region & Primorsky Territory \\
\hline Republic of Karelia & Rostov region & Amur region \\
\hline Republic of Komi & Republic of Dagestan & Jewish autonomous area \\
\hline Arkhangelsk region & Republic of Ingushetia & \\
\hline Nenets Autonomous Okrug & Republic of Kabardino-Balkaria & HL (High-Low) Regions \\
\hline Vologda region & Republic of Karachaevo-Cherkessia & Lipetsk region \\
\hline Leningrad region & Republic of Northen Ossetia - Alania & Republic of Mordovia \\
\hline Murmansk region & Stavropol Territory & Samara region \\
\hline Novgorod region & Saratov region & Chelyabinsk region \\
\hline Pskov region & Republic of Altay & Novosibirsk region \\
\hline Saint-Petersburg & Republic of Buryatia & \\
\hline Republic of Marii El & Republic of Tyva & \\
\hline Republic of Tatarstan & Republic of Khakassia & \\
\hline Republic of Udmurtia & Altay Territory & \\
\hline Republic of Chuvashia & Zabaykalsky Territory & \\
\hline Perm territory & Irkutsk region & \\
\hline Kirov region & Kemerovo region & \\
\hline \multicolumn{3}{|l|}{ Nizhny Novgorod region } \\
\hline \multicolumn{3}{|l|}{ Orenburg region } \\
\hline \multicolumn{3}{|l|}{ Sverdlovsk region } \\
\hline \multicolumn{3}{|l|}{ Tumen region } \\
\hline \multicolumn{3}{|l|}{ Khanty-Mansi Autonomous Area - Yugra } \\
\hline \multicolumn{3}{|l|}{ Yamal-Nenets autonomous region } \\
\hline \multicolumn{3}{|l|}{ Krasnoyarsk Territory } \\
\hline \multicolumn{3}{|l|}{ Omsk region } \\
\hline \multicolumn{3}{|l|}{ Republic of Sakha (Yakutia) } \\
\hline \multicolumn{3}{|l|}{ Kamchatka territory } \\
\hline \multicolumn{3}{|l|}{ Khabarovsk Territory } \\
\hline \multicolumn{3}{|l|}{ Magadan region } \\
\hline \multicolumn{3}{|l|}{ Sakhalin region } \\
\hline Chukotka Autonomous Okrug & & \\
\hline
\end{tabular}

with a group which had approximately the same mean. As a result, regions 40 and 54 were joined to the $L L 2$ group.

The resulting division by employment groups is depicted below.

Regions from the $L L 1$ group are mainly located in the south of Russia. These are mainly agricultural areas characterized by a high level of informal employment.

It should be noted that the authoritative experts on the Russian labor market in their re- port ([26] Gimpelson et al, 2017) also divide the Russian outsider regions into two groups: a group of southern republics and a group of regions of Southern Siberia (details can be found in [26]). They note that "the regions within each group have very similar structural and natural-geographical characteristics."

In previous research (see [25] Danilenko et al., 2017), we analyzed the difference in spatial effects and the determinants of unemployment rate for three clubs of Russian regions $(H H, L L, H L)$. In the 


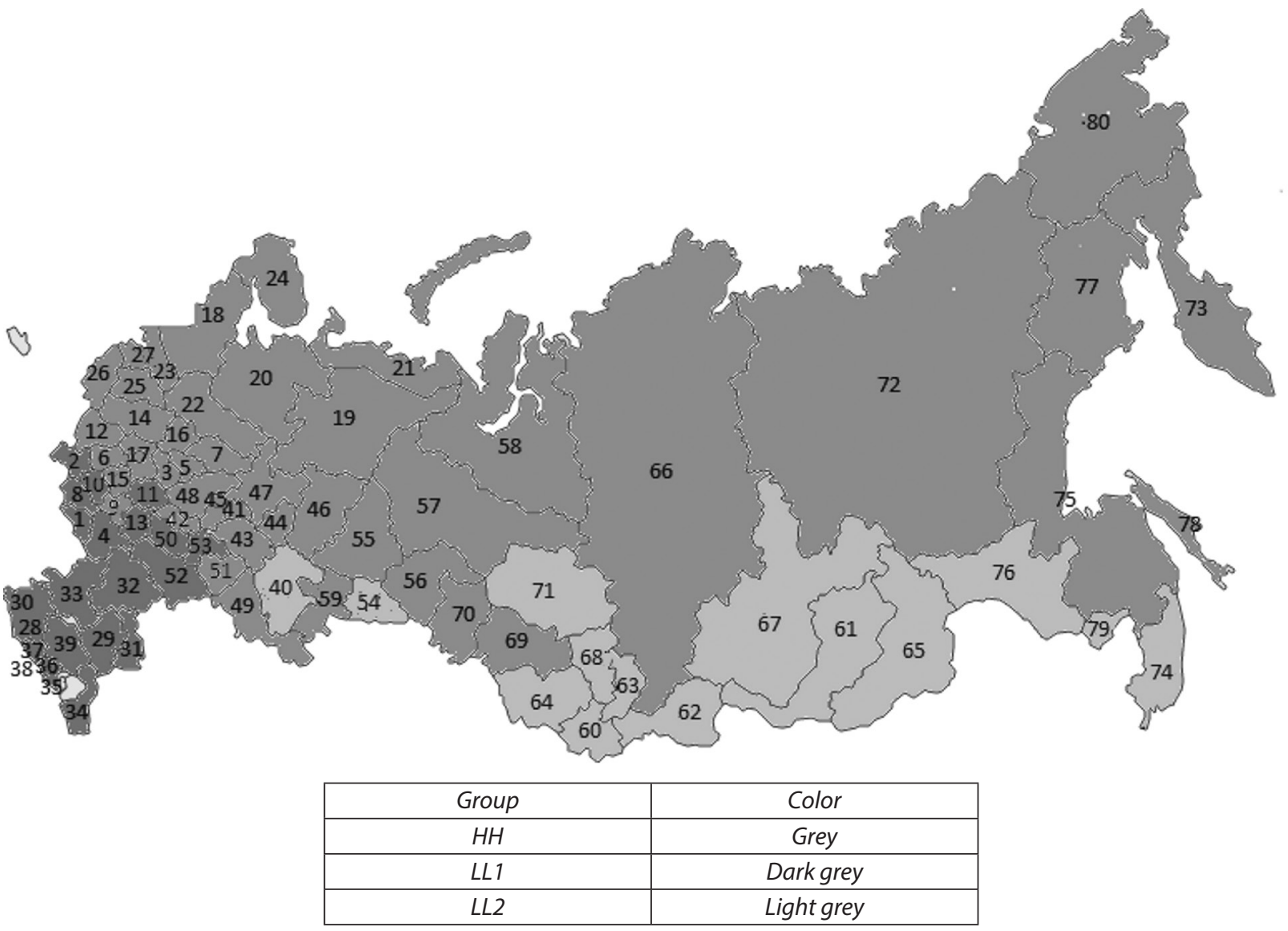

Fig. Employment groups

Table 3

The list of Russian regions obtained by ranking

\begin{tabular}{|l|l|l|}
\hline $\begin{array}{c}\text { Employment (from highest to lowest } \\
\text { level) }\end{array}$ & \multicolumn{1}{|c|}{$\begin{array}{c}\text { Unemployment (from lowest to } \\
\text { highest level) }\end{array}$} & $\begin{array}{c}\text { Buying power of nominal wage (from } \\
\text { highest to lowest) }\end{array}$ \\
\hline Chukotka Autonomous Okrug & Moscow & Nenets Autonomous Okrug \\
\hline Yamal-Nenets Autonomous region & Saint-Petersburg & Yamal-Nenets Autonomous region \\
\hline Magadan region & Chukotka Autonomous Okrug & Tumen region \\
\hline Saint-Petersburg & Samara region & $\begin{array}{l}\text { Khanty-Mansi Autonomous Area } \\
\text { - Yugra }\end{array}$ \\
\hline Moscow & Tula region & Chukotka Autonomous Okrug \\
\hline $\begin{array}{l}\text { Khanty-Mansi Autonomous Area } \\
\text { Yugra }\end{array}$ & Yamal-Nenets Autonomous region & Magadan region \\
\hline Murmansk region & Lipetsk region & Moscow \\
\hline Kamchatka territory & Belgorod region & Saint-Petersburg \\
\hline Tumen region & Republic of Mordovia & Sakhalin region \\
\hline Nenets Autonomous Okrug & Yaroslavl region & Republic of Komi \\
\hline Leningrad region & Novgorod region & Krasnoyarsk Territory \\
\hline Samara region & Kostroma region & Murmansk region \\
\hline Kaluga region & Kaluga region & Republic of Sakha (Yakutia) \\
\hline Sakhalin region & Leningrad region & Kemerovo region \\
\hline Republic of Mordovia & Magadan region & Irkutsk region \\
\hline Yaroslavl region & Republic of Tatarstan & Tomsk region \\
\hline Republic of Udmurtia & Tver region & Kamchatka territory \\
\hline Kostroma region & Nizhny Novgorod region & Arkhangelsk region \\
\hline Novgorod region & Ryazan region & Republic of Tatarstan \\
\hline Vologda region & Penza region & Sverdlovsk region \\
\hline
\end{tabular}


Continued table 3

\begin{tabular}{|c|c|c|}
\hline $\begin{array}{c}\text { Employment (from highest to lowest } \\
\text { level) }\end{array}$ & $\begin{array}{c}\text { Unemployment (from lowest to } \\
\text { highest level) }\end{array}$ & $\begin{array}{c}\text { Buying power of nominal wage (from } \\
\text { highest to lowest) }\end{array}$ \\
\hline Nizhny Novgorod region & Chelyabinsk region & Zabaykalsky Territory \\
\hline Sverdlovsk region & Tumen region & Leningrad region \\
\hline Krasnoyarsk Territory & Ivanovo region & Republic of Karelia \\
\hline Vladimir region & Voronezh region & Chelyabinsk region \\
\hline Tver region & Vologda region & Omsk region \\
\hline Republic of Tatarstan & Kursk region & Republic of Bashkortostan \\
\hline Smolensk region & Arkhangelsk region & Republic of Khakassia \\
\hline Kirov region & Krasnodar Territory & Kaluga region \\
\hline Lipetsk region & Vladimir region & Amur region \\
\hline Khabarovsk Territory & Orel region & Vologda region \\
\hline Arkhangelsk region & Sverdlovsk region & Belgorod region \\
\hline Chelyabinsk region & $\begin{array}{l}\text { Khanty-Mansi Autonomous Area } \\
\text { - Yugra }\end{array}$ & Khabarovsk Territory \\
\hline Republic of Sakha (Yakutia) & Bryansk region & Novosibirsk region \\
\hline Republic of Komi & Ulyanovsk region & Novgorod region \\
\hline Republic of Karelia & Orenburg region & Republic of Tyva \\
\hline Tula region & Republic of Bashkortostan & Astrakhan region \\
\hline Republic of Chuvashia & Krasnoyarsk Territory & Yaroslavl region \\
\hline Ivanovo region & Smolensk region & Republic of Buryatia \\
\hline Astrakhan region & Stavropol Territory & Lipetsk region \\
\hline Perm territory & Khabarovsk Territory & Tula region \\
\hline Primorsky Territory & Amur region & Orenburg region \\
\hline Pskov region & Saratov region & Perm territory \\
\hline Republic of Marii El & Rostov region & Republic of Udmurtia \\
\hline Novosibirsk region & Novosibirsk region & Primorsky Territory \\
\hline Belgorod region & Tambov region & Nizhny Novgorod region \\
\hline Orenburg region & Sakhalin region & Saratov region \\
\hline Kursk region & Kamchatka territory & Krasnodar Territory \\
\hline Irkutsk region & Pskov region & Samara region \\
\hline Omsk region & Kirov region & Jewish Autonomous area \\
\hline Orel region & Nenets Autonomous Okrug & Tver region \\
\hline Kemerovo region & Republic of Udmurtia & Volgograd region \\
\hline Ulyanovsk region & Perm territory & Penza region \\
\hline Volgograd region & Volgograd region & Smolensk region \\
\hline Amur region & Murmansk region & Orel region \\
\hline Republic of Bashkortostan & Kemerovo region & Ryazan region \\
\hline Bryansk region & Republic of Karelia & Kostroma region \\
\hline Saratov region & Omsk region & Rostov region \\
\hline Tomsk region & Republic of Khakassia & Kursk region \\
\hline Republic of Northen Ossetia - Alania & Primorsky Territory & Republic of Chuvashia \\
\hline Rostov region & Republic of Chuvashia & Vladimir region \\
\hline Penza region & Altay Territory & Republic of Marii El \\
\hline Krasnodar Territory & Tomsk region & Ulyanovsk region \\
\hline Altay Territory & Republic of Marii El & Pskov region \\
\hline Republic of Khakassia & Republic of Sakha (Yakutia) & Republic of Ingushetia \\
\hline Ryazan region & Jewish Autonomous area & Kurgan region \\
\hline Voronezh region & Astrakhan region & Voronezh region \\
\hline Republic of Altay & Republic of Komi & Bryansk region \\
\hline Stavropol Territory & Republic of Adygea & Kirov region \\
\hline Tambov region & Republic of Northen Ossetia - Alania & Republic of Mordovia \\
\hline
\end{tabular}


End of table 3

\begin{tabular}{|l|l|l|}
\hline $\begin{array}{c}\text { Employment (from highest to lowest } \\
\text { level) }\end{array}$ & \multicolumn{1}{|c|}{$\begin{array}{c}\text { Unemployment (from lowest to } \\
\text { highest level) }\end{array}$} & $\begin{array}{l}\text { Buying power of nominal wage (from } \\
\text { highest to lowest) }\end{array}$ \\
\hline Jewish Autonomous area & Irkutsk region & Tambov region \\
\hline Kurgan region & Zabaykalsky Territory & Republic of Northen Ossetia - Alania \\
\hline Republic of Kalmykia & Kurgan region & Stavropol Territory \\
\hline Zabaykalsky Territory & Republic of Buryatia & Republic of Adygea \\
\hline Republic of Karachaevo-Cherkessia & Republic of Altay & Altay Territory \\
\hline Republic of Buryatia & Republic of Karachaevo-Cherkessia & Republic of Altay \\
\hline Republic of Adygea & Republic of Kabardino-Balkaria & Republic of Kabardino-Balkaria \\
\hline Republic of Dagestan & Republic of Dagestan & Ivanovo region \\
\hline Republic of Kabardino-Balkaria & Republic of Kalmykia & Republic of Karachaevo-Cherkessia \\
\hline Republic of Tyva & Republic of Tyva & Republic of Kalmykia \\
\hline Republic of Ingushetia & Republic of Ingushetia & Republic of Dagestan \\
\hline
\end{tabular}

Table 4

List of regions with numbers

\begin{tabular}{|c|c|c|c|}
\hline Number & Region & Number & Region \\
\hline 1 & Belgorod region & 41 & Republic of Marii El \\
\hline 2 & Bryansk region & 42 & Republic of Mordovia \\
\hline 3 & Vladimir region & 43 & Republic of Tatarstan \\
\hline 4 & Voronezh region & 44 & Republic of Udmurtia \\
\hline 5 & Ivanovo region & 45 & Republic of Chuvashia \\
\hline 6 & Kaluga region & 46 & Perm territory \\
\hline 7 & Kostroma region & 47 & Kirov region \\
\hline 8 & Kursk region & 48 & Nizhny Novgorod region \\
\hline 9 & Lipetsk region & 49 & Orenburg region \\
\hline 10 & Orel region & 50 & Penza region \\
\hline 11 & Ryazan region & 51 & Samara region \\
\hline 12 & Smolensk region & 52 & Saratov region \\
\hline 13 & Tambov region & 53 & Ulyanovsk region \\
\hline 14 & Tver region & 54 & Kurgan region \\
\hline 15 & Tula region & 55 & Sverdlovsk region \\
\hline 16 & Yaroslavl region & 56 & Tumen region \\
\hline 17 & Moscow & 57 & Khanty-Mansi Autonomous Area - Yugra \\
\hline 18 & Republic of Karelia & 58 & Yamal-Nenets autonomous region \\
\hline 19 & Republic of Komi & 59 & Chelyabinsk region \\
\hline 20 & Arkhangelsk region & 60 & Republic of Altay \\
\hline 21 & Nenets Autonomous Okrug & 61 & Republic of Buryatia \\
\hline 22 & Vologda region & 62 & Republic of Tyva \\
\hline 23 & Leningrad region & 63 & Republic of Khakassia \\
\hline 24 & Murmansk region & 64 & Altay Territory \\
\hline 25 & Novgorod region & 65 & Zabaykalsky Territory \\
\hline 26 & Pskov region & 66 & Krasnoyarsk Territory \\
\hline 27 & Saint-Petersburg & 67 & Irkutsk region \\
\hline 28 & Republic of Adygea & 68 & Kemerovo region \\
\hline 29 & Republic of Kalmykia & 69 & Novosibirsk region \\
\hline 30 & Krasnodar Territory & 70 & Omsk region \\
\hline 31 & Astrakhan region & 71 & Tomsk region \\
\hline 32 & Volgograd region & 72 & Republic of Sakha (Yakutia) \\
\hline 33 & Rostov region & 73 & Kamchatka territory \\
\hline 34 & Republic of Dagestan & 74 & Primorsky Territory \\
\hline 35 & Republic of Ingushetia & 75 & Khabarovsk Territory \\
\hline 36 & Republic of Kabardino-Balkaria & 76 & Amur region \\
\hline
\end{tabular}


End of table 4

\begin{tabular}{|c|l|c|l|}
\hline Number & \multicolumn{1}{|c|}{ Region } & Number & \multicolumn{1}{c|}{ Region } \\
\hline 37 & Republic of Karachaevo-Cherkessia & 77 & Magadan region \\
\hline 38 & Republic of Northen Ossetia - Alania & 78 & Sakhalin region \\
\hline 39 & Stavropol Territory & 79 & Jewish autonomous area \\
\hline 40 & Republic of Bashkortostan & 80 & Chukotka Autonomous Okrug \\
\hline
\end{tabular}

research reported here, we decided to test similar hypotheses for three employment groups.

H1: spatial effects for the $H H, L L 1$, and $L L 2$ groups differ;

H2: the determinants of employment for the $H H, L L 1$, and $L L 2$ groups differ.

\subsection{The Data, the Dependent and the Explanatory Variables}

As said, our sample consisted of 80 regions. Due to data availability, the employment rate was calculated on the population aged between 15 to 72.

To explain existing levels of employment rate (variable empl.) and to test two research hypotheses, three groups of variables were chosen: 1) variables concerning the attractiveness of the region; 2) socio-demographic variables; and 3) variables concerning the industrial structure of the employed population. The first group of variables consisted of four indicators: (i) GRP per capita (variable grppercap_1, thousand rubles in prices of basic year), (ii) population density (variable density, people per square $\mathrm{km}$ ), (iii) the share of urban population (variable urban_share, \%), (iv) net migration rate (migration_1, number of migrants per 10000 population, may be positive or negative). The socio-demographic features of the population consisted of variables characterizing the age structure of the population and the stock of human capital. To illustrate the age structure, the shares of people below and above working age were taken as variables (below and above, \%). Working age in Russia is above 16 and below retirement age, which was 60 years for men and 55 for women during the studied period. The stock of human capital was measured as the share of the employed population with a higher education (variable high_educ, \%), where 'higher education' means that someone has at least a higher professional education according to the FSSS classification. The sectoral structure is one of the most important features in explaining the regional employment rate. Consequently, we used the Hirschman-Herfindahl Index (variable $h h_{-}$1) to characterize the industrial structure of each region; and it is used as a measure of the region's degree of sectoral specialization.

$$
H H I=S_{1}^{2}+S_{2}^{2}+\ldots+S_{n}^{2},
$$

where $S_{1}{ }^{2}, S_{2}{ }^{2}, \ldots, S_{n}{ }^{2}$ are shares of people employed in sectors of economic activity (agriculture, construction, wholesale and retail trade, public sector (consisting of education and health services), mining, manufacturing, services). The region is more monopolized if the $h h$ value is closer to 1 .

To avoid the problem of endogeneity, we used the first time lag of the variables grp, migration, $h$.

We now compare the descriptive statistics of variables for different groups (see Table 4).

There are disparities between $H H, L L 1$ and $L L 2$ groups. For example, almost all mean values for variables that characterize the attractiveness of the region are higher in the $H H$ group.

\section{Methodology of the Econometric Modeling}

To test the two main research hypotheses, we used the following modification of the SAR (Spatial Auto Regression) model:

$$
\begin{gathered}
\left(\begin{array}{c}
Y_{i H} \\
Y_{i L 1} \\
Y_{i L 2}
\end{array}\right)_{t}=\tau\left(\begin{array}{c}
Y_{i H} \\
Y_{i L 1} \\
Y_{i L 2}
\end{array}\right)_{t-1}+\rho_{H}\left(\begin{array}{c}
W Y_{i H} \\
0 \\
0
\end{array}\right)_{t}+ \\
+\rho_{L 1}\left(\begin{array}{c}
0 \\
W Y_{i L 1} \\
0
\end{array}\right)_{t}+\rho_{L 2}\left(\begin{array}{c}
0 \\
0 \\
W Y_{i L 2}
\end{array}\right)_{t}+ \\
+\left(\begin{array}{c}
X_{i H} \\
0 \\
0
\end{array}\right)_{t} \beta_{H}+\left(\begin{array}{c}
0 \\
X_{i L 1} \\
0
\end{array}\right)_{t} \beta_{L 1}+\left(\begin{array}{c}
0 \\
0 \\
X_{i L 2}
\end{array}\right)_{t} \beta_{L 2}+ \\
+\left(\begin{array}{c}
\alpha_{i H} \\
\alpha_{i L 1} \\
\alpha_{i L 2}
\end{array}\right)+c_{t}+\left(\begin{array}{l}
u_{i H} \\
u_{i L 1} \\
u_{i L 2}
\end{array}\right)_{t},
\end{gathered}
$$

where $Y$ is employment in group $15-72, W Y$ is spatial lag, $X$ is a matrix of explanatory variables, $\alpha$ is a vector of fixed effects, $u$ is a vector of errors (we split them in three parts), $c$ is a vector of time effects (set of dummy variables for 20072016 years).

Let us formulate our hypotheses in a form convenient for empirical verification:

Hypothesis 1. There are no differences of spatial effects in regional groups.

Alternative hypothesis 1 . There are differences of spatial effects in regional groups. 
Table 5

Descriptive statistics for the variables

\begin{tabular}{|c|c|c|c|c|c|c|}
\hline Variable & & Mean & Std. Dev. & Min & Max & Observations \\
\hline \multicolumn{7}{|c|}{ All Russia } \\
\hline \multirow{3}{*}{ empl } & overall & 62.528 & 5.955 & 16.500 & 81.200 & $N=960$ \\
\hline & between & & 5.505 & 34.475 & 78.783 & $n=80$ \\
\hline & within & & 2.345 & 44.553 & 78.853 & $T=12$ \\
\hline \multirow{3}{*}{ wcbempl } & overall & 62.939 & 3.777 & 36.439 & 78.836 & $N=960$ \\
\hline & between & & 3.386 & 46.110 & 76.357 & $n=80$ \\
\hline & within & & 1.713 & 53.267 & 73.657 & $T=12$ \\
\hline \multirow{3}{*}{ widempl } & overall & 62.138 & 2.427 & 41.332 & 65.947 & $N=960$ \\
\hline & between & & 1.836 & 49.799 & 64.295 & $n=80$ \\
\hline & within & & 1.600 & 53.671 & 70.136 & $T=12$ \\
\hline \multirow{3}{*}{ grppercap_1 } & overall & 96963.860 & 117139.900 & 2133.539 & 1035858.000 & $N=960$ \\
\hline & between & & 101129.200 & 11439.280 & 589271.300 & $n=80$ \\
\hline & within & & 60099.540 & -387423.000 & 543550.500 & $T=12$ \\
\hline \multirow{3}{*}{ urbanshare } & overall & 0.694 & 0.126 & 0.260 & 1.000 & $N=960$ \\
\hline & between & & 0.126 & 0.278 & 1.000 & $n=80$ \\
\hline & within & & 0.011 & 0.653 & 0.738 & $T=12$ \\
\hline \multirow{3}{*}{ below } & overall & 17.701 & 3.548 & 12.100 & 34.400 & $N=960$ \\
\hline & between & & 3.450 & 13.025 & 31.158 & $n=80$ \\
\hline & within & & 0.907 & 15.243 & 20.943 & $T=12$ \\
\hline \multirow{3}{*}{ above } & overall & 21.397 & 4.931 & 5.500 & 30.200 & $N=960$ \\
\hline & between & & 4.638 & 8.258 & 28.125 & $n=80$ \\
\hline & within & & 1.747 & 16.905 & 27.805 & $T=12$ \\
\hline \multirow{3}{*}{ migration_1 } & overall & -9.754 & 54.749 & -499.000 & 197.000 & $N=960$ \\
\hline & between & & 43.594 & -142.333 & 107.500 & $n=80$ \\
\hline & within & & 33.449 & -492.338 & 172.079 & $T=12$ \\
\hline \multirow{3}{*}{ density } & overall & 73.322 & 387.276 & 0.069 & 3752.572 & $N=960$ \\
\hline & between & & 388.906 & 0.070 & 3482.613 & $n=80$ \\
\hline & within & & 21.661 & -146.362 & 343.280 & $T=12$ \\
\hline \multirow{3}{*}{ high_educ } & overall & 26.654 & 5.678 & 12.500 & 50.000 & $N=960$ \\
\hline & between & & 4.443 & 18.925 & 47.758 & $n=80$ \\
\hline & within & & 3.567 & 14.671 & 40.521 & $T=12$ \\
\hline \multirow{3}{*}{ hh_1 } & overall & 0.293 & 0.060 & 0.204 & 0.635 & $N=960$ \\
\hline & between & & 0.056 & 0.215 & 0.557 & $n=80$ \\
\hline & within & & 0.023 & 0.196 & 0.560 & $T=12$ \\
\hline \multicolumn{7}{|c|}{ HH group } \\
\hline \multirow{3}{*}{ empl } & overall & 65.681 & 3.855 & 57.700 & 81.200 & $N=528$ \\
\hline & between & & 3.417 & 61.800 & 78.783 & $n=44$ \\
\hline & within & & 1.853 & 58.898 & 70.748 & $T=12$ \\
\hline \multirow{3}{*}{ wcbempl } & overall & 64.648 & 2.691 & 58.622 & 78.836 & $N=528$ \\
\hline & between & & 2.341 & 60.473 & 76.357 & $n=44$ \\
\hline & within & & 1.369 & 60.239 & 67.666 & $T=12$ \\
\hline \multirow{3}{*}{ widempl } & overall & 62.897 & 1.521 & 59.289 & 65.947 & $N=528$ \\
\hline & between & & 0.598 & 61.473 & 64.295 & $n=44$ \\
\hline & within & & 1.401 & 59.961 & 65.113 & $T=12$ \\
\hline \multirow{3}{*}{ grppercap_1 } & overall & 124489.100 & 146080.500 & 2133.539 & 1035858.000 & $N=528$ \\
\hline & between & & 125809.100 & 34761.040 & 589271.300 & $n=44$ \\
\hline & within & & 76432.750 & -359897.800 & 571075.700 & $T=12$ \\
\hline \multirow{3}{*}{ urbanshare } & overall & 0.755 & 0.095 & 0.573 & 1.000 & $N=528$ \\
\hline & between & & 0.096 & 0.588 & 1.000 & $n=44$ \\
\hline & within & & 0.011 & 0.715 & 0.800 & $T=12$ \\
\hline \multirow{3}{*}{ below } & overall & 16.929 & 2.629 & 12.100 & 24.800 & $N=528$ \\
\hline & between & & 2.501 & 13.025 & 23.858 & $n=44$ \\
\hline & within & & 0.887 & 15.496 & 19.288 & $T=12$ \\
\hline
\end{tabular}


Continued table 5

\begin{tabular}{|c|c|c|c|c|c|c|}
\hline Variable & & Mean & Std. Dev. & Min & Max & Observations \\
\hline \multirow{3}{*}{ above } & overall & 21.580 & 5.011 & 5.500 & 30.200 & $N=528$ \\
\hline & between & & 4.704 & 8.258 & 28.125 & $n=44$ \\
\hline & within & & 1.855 & 17.089 & 27.989 & $T=12$ \\
\hline \multirow{3}{*}{ migration_1 } & overall & -7.242 & 57.181 & -223.000 & 197.000 & $N=528$ \\
\hline & between & & 48.814 & -142.333 & 107.500 & $n=44$ \\
\hline & within & & 30.604 & -190.325 & 174.591 & $T=12$ \\
\hline \multirow{3}{*}{ density } & overall & 107.836 & 519.274 & 0.069 & 3752.572 & $N=528$ \\
\hline & between & & 523.951 & 0.070 & 3482.613 & $n=44$ \\
\hline & within & & 29.178 & -111.848 & 377.794 & $T=12$ \\
\hline \multirow{3}{*}{ high_educ } & overall & 26.414 & 6.174 & 12.500 & 50.000 & $N=528$ \\
\hline & between & & 5.142 & 19.035 & 47.758 & $n=44$ \\
\hline & within & & 3.497 & 14.431 & 35.189 & $T=12$ \\
\hline \multirow{3}{*}{ hh_1 } & overall & 0.291 & 0.069 & 0.205 & 0.635 & $N=528$ \\
\hline & between & & 0.064 & 0.215 & 0.557 & $n=44$ \\
\hline & within & & 0.028 & 0.193 & 0.558 & $T=12$ \\
\hline \multicolumn{7}{|c|}{$L L 1$ group } \\
\hline \multirow{3}{*}{ empl } & overall & 58.474 & 6.710 & 16.500 & 67.300 & $N=264$ \\
\hline & between & & 5.966 & 34.475 & 62.725 & $n=22$ \\
\hline & within & & 3.306 & 40.499 & 74.799 & $T=12$ \\
\hline \multirow{3}{*}{ wcbempl } & overall & 60.236 & 4.420 & 36.439 & 67.223 & $N=264$ \\
\hline & between & & 3.800 & 46.110 & 64.996 & $n=22$ \\
\hline & within & & 2.387 & 50.565 & 70.954 & $T=12$ \\
\hline \multirow{3}{*}{ widempl } & overall & 60.688 & 3.500 & 41.332 & 65.159 & $N=264$ \\
\hline & between & & 2.887 & 49.799 & 63.220 & $n=22$ \\
\hline & within & & 2.064 & 52.221 & 68.686 & $T=12$ \\
\hline \multirow{3}{*}{ grppercap_1 } & overall & 59339.110 & 43394.850 & 3310.776 & 291518.000 & $N=264$ \\
\hline & between & & 35287.700 & 11439.280 & 161948.200 & $n=22$ \\
\hline & within & & 26267.330 & -33631.360 & 188908.800 & $T=12$ \\
\hline \multirow{3}{*}{ urbanshare } & overall & 0.608 & 0.106 & 0.384 & 0.767 & $N=264$ \\
\hline & between & & 0.108 & 0.413 & 0.760 & $n=22$ \\
\hline & within & & 0.011 & 0.580 & 0.644 & $T=12$ \\
\hline \multirow{3}{*}{ below } & overall & 17.756 & 4.102 & 13.600 & 33.400 & $N=264$ \\
\hline & between & & 4.127 & 14.233 & 30.425 & $n=22$ \\
\hline & within & & 0.713 & 15.431 & 20.731 & $T=12$ \\
\hline \multirow{3}{*}{ above } & overall & 22.358 & 4.960 & 7.600 & 29.900 & $N=264$ \\
\hline & between & & 4.839 & 9.408 & 27.592 & $n=22$ \\
\hline & within & & 1.472 & 19.533 & 26.474 & $T=12$ \\
\hline \multirow{3}{*}{ migration_1 } & overall & -2.585 & 55.750 & -499.000 & 148.000 & $N=264$ \\
\hline & between & & 37.061 & -86.667 & 75.833 & $n=22$ \\
\hline & within & & 42.332 & -485.169 & 161.832 & $T=12$ \\
\hline \multirow{3}{*}{ density } & overall & 45.202 & 26.455 & 3.726 & 143.530 & $N=264$ \\
\hline & between & & 26.944 & 3.803 & 130.743 & $n=22$ \\
\hline & within & & 2.066 & 29.739 & 57.989 & $T=12$ \\
\hline \multirow{3}{*}{ high_educ } & overall & 28.120 & 4.833 & 16.600 & 46.000 & $N=264$ \\
\hline & between & & 3.054 & 23.233 & 36.417 & $n=22$ \\
\hline & within & & 3.797 & 17.461 & 41.986 & $T=12$ \\
\hline \multirow{3}{*}{ hh_1 } & overall & 0.308 & 0.045 & 0.238 & 0.456 & $N=264$ \\
\hline & between & & 0.043 & 0.253 & 0.433 & $n=22$ \\
\hline & within & & 0.016 & 0.268 & 0.406 & $T=12$ \\
\hline \multicolumn{7}{|c|}{ LL2 group } \\
\hline \multirow{3}{*}{ empl } & overall & 58.990 & 3.977 & 45.800 & 65.900 & $N=168$ \\
\hline & between & & 3.625 & 48.225 & 62.917 & $n=14$ \\
\hline & within & & 1.882 & 52.032 & 62.932 & $T=12$ \\
\hline
\end{tabular}


End of table 5

\begin{tabular}{|c|c|c|c|c|c|c|}
\hline Variable & & Mean & Std. Dev. & Min & Max & Observations \\
\hline \multirow{3}{*}{ wcbempl } & overall & 61.815 & 2.500 & 55.573 & 67.400 & $N=168$ \\
\hline & between & & 2.143 & 57.311 & 64.955 & $n=14$ \\
\hline & within & & 1.399 & 57.884 & 64.857 & $T=12$ \\
\hline \multirow{3}{*}{ widempl } & overall & 62.032 & 1.441 & 59.104 & 65.172 & $N=168$ \\
\hline & between & & 0.559 & 61.020 & 63.062 & $n=14$ \\
\hline & within & & 1.336 & 59.455 & 64.142 & $T=12$ \\
\hline \multirow{3}{*}{ grppercap_1 } & overall & 69580.570 & 55707.250 & 5249.425 & 309864.000 & $N=168$ \\
\hline & between & & 44904.770 & 21177.230 & 170118.100 & $n=14$ \\
\hline & within & & 34923.890 & -35537.610 & 209326.500 & $T=12$ \\
\hline \multirow{3}{*}{ urbanshare } & overall & 0.637 & 0.135 & 0.260 & 0.858 & $N=168$ \\
\hline & between & & 0.139 & 0.278 & 0.853 & $n=14$ \\
\hline & within & & 0.013 & 0.611 & 0.663 & $T=12$ \\
\hline \multirow{3}{*}{ below } & overall & 20.042 & 4.072 & 15.400 & 34.400 & $N=168$ \\
\hline & between & & 4.026 & 16.117 & 31.158 & $n=14$ \\
\hline & within & & 1.200 & 17.584 & 23.284 & $T=12$ \\
\hline \multirow{3}{*}{ above } & overall & 19.310 & 3.960 & 9.200 & 28.500 & $N=168$ \\
\hline & between & & 3.648 & 9.958 & 24.833 & $n=14$ \\
\hline & within & & 1.803 & 16.377 & 22.977 & $T=12$ \\
\hline \multirow{3}{*}{ migration_1 } & overall & -28.917 & 39.109 & -159.000 & 79.000 & $N=168$ \\
\hline & between & & 30.738 & -80.000 & 28.917 & $n=14$ \\
\hline & within & & 25.435 & -126.167 & 46.833 & $T=12$ \\
\hline \multirow{3}{*}{ density } & overall & 9.036 & 9.080 & 0.750 & 29.660 & $N=168$ \\
\hline & between & & 9.332 & 1.852 & 28.982 & $n=14$ \\
\hline & within & & 1.047 & 0.628 & 10.968 & $T=12$ \\
\hline \multirow{3}{*}{ high_educ } & overall & 25.107 & 4.697 & 14.500 & 36.200 & $N=168$ \\
\hline & between & & 3.320 & 18.925 & 30.842 & $n=14$ \\
\hline & within & & 3.430 & 15.490 & 32.707 & $T=12$ \\
\hline \multirow{3}{*}{ hh_1 } & overall & 0.277 & 0.043 & 0.204 & 0.371 & $N=168$ \\
\hline & between & & 0.042 & 0.217 & 0.352 & $n=14$ \\
\hline & within & & 0.015 & 0.247 & 0.322 & $T=12$ \\
\hline
\end{tabular}

Formal main and alternative hypotheses 1 :

$$
\begin{gathered}
H_{0}: \rho_{H}=\rho_{L 1}=\rho_{L 2}, \\
H_{1}: \rho_{H} \neq \rho_{L 1} \text { or } \rho_{H} \neq \rho_{L 2} .
\end{gathered}
$$

Hypothesis 2. There are no differences in the influence of the factors on employment rates in the regions belonging to different regional clubs.

Alternative hypothesis 2. There are differences in the influence of the factors on employment rates in the regions belonging to different regional clubs.

Formal main and alternative hypotheses 2 :

$$
\begin{gathered}
H_{0}: \beta_{H}=\beta_{L 1}=\beta_{L 2}, \\
H_{1}: \beta_{H} \neq \beta_{L 1} \text { or } \beta_{H} \neq \beta_{L 2} .
\end{gathered}
$$

The split spatial lags in our model were endogenous. To resolve the problem of endogeneity difference, we adopted the GMM ([27] Arellano and Bond, 1991) method of estimation. However, application of this method to our initial specification (with all explanatory variables, divided into several parts) required a number of instruments much larger than the number of regions.
According to Roodman (2009), this leads to a bias in the parameter estimation. To avoid this problem we had to use the Arellano-Bond approach for the estimation and drastically restrict the number of instruments. Moreover, in order to consider the possible bias in the parameters' estimation at a small time interval but with a large number of observation units, we adopted a GMM modification for models with fixed effects, similarly to [28] Lee and $\mathrm{Yu}$ (2010). In addition, a large number of variables may also lead to the problem of multicollinearity of the data. To increase the efficiency of the estimates, we removed groups of insignificant variables from the model one by one (after a preliminary test of the corresponding statistical hypotheses). The technique that we used was an extension of the conventional backward stepwise method. To test the robustness of the result of the estimation, we re-estimated our model with an inverted distance weighted matrix instead of the matrix of common borders. The results of the estimation are presented in the next section. 


\section{TheResults of the Estimation}

In this section, we present the final results of our main estimations (Table 6). For each model, we also present the results of post-estimation procedures. Estimates of the coefficients obtained by the Arellano-Bond method are consistent under the following conditions ([29] Greene, 2012, p. 400): 1) errors $u_{i t}$ must be serially uncorrelated; 2) moment conditions (consisting in the orthogonality of the errors and instruments) must be correct. The Arellano-Bond approach, using the equations in difference, makes it possible to avoid the endogeneity problem with the elimination of individual effects. It is for this reason that the errors in the difference equation must be identified as first-order autocorrelations and not revealed as higher-order autocorrelations (Arellano and Bond test). The second condition is verified by the Sargan test of instruments' validity. These two conditions are verified for all the models estimated.

Spatial effects for the three employment groups were different. For the LL2 group of regions, the spatial effects were insignificant; hence employment in the regions of the $L L 2$ group does not depend on the local labor markets of other regions. For the group of $H H$ regions, only spatial effects for the inverse distance weighting matrix are significant. Consequently, each region of the $H H$ group is affected by the rest of Russia's regions, and the extent of this influence decreases with the increase in geographical distance between regions. Employment in the $H H$ region group varies according to the general situation in the country.

The most interesting spatial effects were revealed for the regions in the $L L 1$ group. For a common boundary weighting matrix, they were negative, and for a weighting matrix of inverted distances, they were positive. Thus, in the $L L 1$ group of regions (in the south of Russia), there is a mechanism of competition for labor resources with neighboring regions. If in one of the southern regions the situation on the labor market improves, then it draws labor resources from neighboring regions. At the same time, if the overall employment situation in Russia improves (or worsens), then similar changes occur in the $L L 1$ group of regions.

In regard to the impact of the explanatory variables, the "group effect" was found for the variables share of urban population, net migration rate, shares of people below and above working age, share of people with higher education.

The influences of GRP per capita and on the level of employment was insignificant.

For $L L 2$ and $H H$ groups of regions, employment was not dependent on the share of the urban population. This can be explained by the presence of
Table 6

The results of estimation

\begin{tabular}{|c|c|c|}
\hline $\begin{array}{c}\text { Dependent Variable } \\
\text { empl }\end{array}$ & modelwcb & modelwid \\
\hline Weighted matrix & $\begin{array}{l}\text { Matrix of } \\
\text { common } \\
\text { borders }\end{array}$ & $\begin{array}{c}\text { Matrix of inverted } \\
\text { distance }\end{array}$ \\
\hline \multicolumn{3}{|l|}{ empl } \\
\hline L1. (time lag) & $0.562^{* * *}$ & $0.553^{* * *}$ \\
\hline \multicolumn{3}{|l|}{ Spatial lags } \\
\hline wcbempL1 & $-0.184^{* * *}$ & \\
\hline wcbempL2 & 0.105 & \\
\hline wcbemplH & 0.125 & \\
\hline widempL1 & & $0.101^{*}$ \\
\hline widempL2 & & 0.234 \\
\hline widemplH & & $0.391^{* * *}$ \\
\hline urbanshareL1 & $-51.186^{* * *}$ & $-29.216^{* * *}$ \\
\hline belowL1 & $-1.017^{* * *}$ & $-0.785^{* * *}$ \\
\hline belowL2 & $-0.415^{* *}$ & -0.139 \\
\hline belowH & $-0.373^{* *}$ & -0.154 \\
\hline aboveL1 & $0.821^{* * \star}$ & $0.813^{* * *}$ \\
\hline migr_1L1 & $0.006^{* * *}$ & $0.007^{* * *}$ \\
\hline migr_1L2 & $0.006^{*}$ & 0.004 \\
\hline migr_1H & $-0.007^{* * *}$ & $-0.006^{* * *}$ \\
\hline dens & $-0.004^{* * *}$ & $-0.003^{*}$ \\
\hline high_edL2 & $0.129^{* *}$ & $0.147^{* *}$ \\
\hline hh_1 & $5.017^{*}$ & $4.857^{*}$ \\
\hline $\mathrm{d} 2007$ & 0.206 & 0.239 \\
\hline $\mathrm{d} 2008$ & -0.164 & -0.332 \\
\hline d2009 & $-1.188^{* * *}$ & $-1.138^{* * *}$ \\
\hline $\mathrm{d} 2010$ & 0.175 & -0.062 \\
\hline $\mathrm{d} 2011$ & 0.583 & 0.122 \\
\hline $\mathrm{d} 2012$ & $1.237^{* * *}$ & 0.338 \\
\hline $\mathrm{d} 2013$ & 0.698 & -0.235 \\
\hline $\mathrm{d} 2014$ & $1.272^{* *}$ & 0.095 \\
\hline $\mathrm{d} 2015$ & $0.992^{*}$ & -0.206 \\
\hline $\mathrm{d} 2016$ & $1.301^{* *}$ & -0.098 \\
\hline _cons & $35.103^{* * *}$ & $11.964^{*}$ \\
\hline $\begin{array}{l}\text { Number of } \\
\text { instruments }\end{array}$ & 62 & 62 \\
\hline \multicolumn{3}{|l|}{$\begin{array}{c}\mathrm{p}-\mathrm{v} \mathrm{AB} \text { test for zero } \\
\text { autocorrelation }\end{array}$} \\
\hline \multicolumn{3}{|l|}{$\begin{array}{c}\text { in first-differenced } \\
\text { errors }\end{array}$} \\
\hline order 1 & 0.000 & 0.000 \\
\hline order 2 & 0.133 & 0.12 \\
\hline p-v Sargan test & 0.477 & 0.254 \\
\hline
\end{tabular}

${ }^{*} p<0.05 ;{ }^{* *} p<0.01 ;{ }^{* * *} p<0.001$.

two opposite tendencies: in a city, it is usually easier to find a job; but for monotowns, of which there are more than 300 in Russia when the city-forming enterprise closes, the situation changes to the op- 
posite. ${ }^{1}$ The increase in the share of urban population reduced employment in the Low-Low1 group. This can be explained by the fact that a large proportion of businesses in the southern regions are engaged in agriculture.

With an increase in the population aged under 16, the level of employment was reduced according to both estimated models only in the $L L 1$ group of regions. This can be explained by the fact that in the North Caucasus regions that belong to this group, the share of young people is very high, and for them, it is difficult to find jobs. Conversely, increasing the proportion of the population over working age increases employment in the $L L 1$ group, because in these regions there are relatively low wages; therefore, on reaching retirement age, people often leave the labor market, preferring informal employment and work on personal plots of land.

The influx of migrants stimulates employment in the $L L 1$ group of regions and decreases employment in the group of $\mathrm{HH}$ regions. This may be because more educated migrants able to compete for well-paid jobs go mainly to the regions of the $\mathrm{HH}$ group.

An increase in the proportion of the population with higher education stimulates employment only in the $L L 2$ group of regions.

Group effects were not found for the variables density and Herfindahl-Hirschman index.

The negative dependence of employment on population density can be explained 1) by competition for jobs, 2) by the problem of monotowns mentioned above, 3 ) by the favorable situation in the labor markets of some sparsely populated northern regions. Perhaps, for this variable, a functional dependence more flexible than the linear one should be used.

A higher Herfindahl-Hirschman index is associated with higher employment. The higher the Herfindahl-Hirschman index, the more the level of specialization in the given region. Thus, in 20052016 in Russia Marshallian effects prevailed.

The results of the estimation also make it possible to draw a conclusion about the negative impact of the 2008-2009 crisis on the level of employment, whereas the crisis of 2014 did not affect it. This is probably because the 2008-2009 crisis was global, while the crisis in 2014 had a local character with effects more delayed and distributed over time.

\section{Conclusions}

\footnotetext{
${ }^{1}$ On the topic of monotowns and the political economy of in dustrial restructuring, see [30] Crowley (2016).
}

In this paper, we have investigated the spatial effects for the regional employment groups in Russia and the differences in the impact factors that explain regional employment. The key results are the following: (1) boundary spatial effects for three groups are different; (2) the differing influence for selected groups of regions was apparent for the share of urban population, net migration rate, the shares of people below and above working age, the share of people with higher education; (3) the influence of GRP is insignificant.

According to our results, these are several (general and specific) policy implications. From a general perspective, (national and regional) economic and labor policies must take the specificity of each group of regions into account; in fact, the same policy measures can generate significantly different consequences in $H H, L L 1$ and $L L 2$ groups of regions; moreover, policies should consider that the (positive) impact on a group of regions can indirectly (negatively or positively) affect other groups of regions. As regards the specific policy implications, the following aspects seem most important: (i) policies favoring a higher level of specialization are suggested due to the positive employment effects in all groups of regions; (ii) an increase of the higher educated proportion of the labor force is recommended because it would increase employment in the South of Siberia and in Zabaikalye; (iii) the increase in migration flows favorably affects the employment of only the $L L 1$ group of regions, where the agricultural sector is well developed; therefore, it is desirable to create favorable conditions for migrants in the South of Russia, while in more densely populated regions of Russia, migrants can compete for jobs with indigenous people, worsening both wage and working conditions; (iv) national and regional economic, educational and labor policies could focus especially on improving the dramatic employment quantity and quality in the group of regions $L L 1$, especially considering the supply-demand mismatches and the difficulties of transition - from education and from unemployment - to employment, also reducing the problem of competing for resources with neighboring regions.

These results are consistent with the findings of the report based on [26] that federal policy in the labor market in Russia should be built with "possible consideration of the heterogeneity of the regions", there are no "simple and quick solutions" to smoothing the differentiation of Russian regions, this problem requires a "strategic and integrated approach."

\section{References}


1. Oschepkov, A. \& Kapelyushnikov, R. (2015). Regionalnyye rynki truda: 15 let razlichiy [Regional labor markets: 15 years of differences]. Higher School of Economics. WP3 series "Problems of the labor market". (In Russ.)

2. Caroleo, F .E. \& Pastore, F. (Eds.) (2010). The labor market impact of the EU enlargement. Berlin: Springer, 342 . doi. org/10.1007/978-3-7908-2164-2_2.

3. Mussida, C. \& Pastore, F. (Eds.) (2015). Geographical Labor Market Imbalances. AIEL Series in Labor Economics, Berlin and Heidelberg, Springer, 370. Retrieved from: https://econpapers.repec.org/RePEc:ail:labook:08.

4. Dolton, P., Bondibene, C. R. \& Stops, M. (2015). Identifying the employment effect of invoking and changing the minimum wage: A spatial analysis of the UK. Labor Economics, 37, 54-76. doi.org/10.1016/j.labeco.2015.09.002. Retrieved from: https:// s100.copyright.com/AppDispatchServlet?publisherName=ELS\&contentID=S0927537115001062\&orderBeanReset=true.

5. Vega, S. H. \& Elhorst, J. P. (2016). A regional unemployment model simultaneously accounting for serial dynamics, spatial dependence and common factors. Regional Science and Urban Economics, 60, 85-95. doi.org/10.1016/j.regsciurbeco.2016.07.002. Retrieved from: https://s100.copyright.com/ AppDispatchServlet?publisherName=ELS\&contentID=S0166046216300862\&orderBeanReset=true.

6. Manning, A. \& Petrongolo, B. (2017). How local are labor markets? Evidence from a spatial job search model. American Economic Review, 107(10), 2877-2907. doi: 10.1257/aer.20131026.

7. Head, K. \& Mayer, T. (2006). Regional wage and employment responses to market potential in the EU. Regional Science and Urban Economics, 36(5), 573-594. doi.org/10.1016/j.regsciurbeco.2006.06.002.

8. Ketterer, T. D. \& Rodríguez-Pose, A. (2016). Institutions vs.'first-nature'geography: What drives economic growth in Europe's regions? Papers in Regional Science. doi 10.1111/pirs.12237.

9. Huber, P. (2007). Regional labor market developments in transition: A survey of the empirical literature. The European Journal of Comparative Economics, 4(2), 263-298.

10. Bah, E. \& Brada, J. (2014). Labor Markets in the Transition Economies: An Overview. The European Journal of Comparative Economics, 11(1), 3-53.

11. Vakulenko, E. S. \& Gurvich, E. T. (2016). Gibkost realnoy zarabotannoy platy v Rossii: sravnitelnyy analiz [Real Wage Flexibility in Russia: Comparative Analysis]. Zhurnal novoy ekonomicheskoy assotsiatsii [Journal of the New Economic Association], 3(31), 67-92. (In Russ.)

12. Kapelyushnikov, R., Kuznetsov, A., \& Kuznetsova, O. (2012). The role of the informal sector, flexible working time and pay in the Russian labor market model. Post-communist economies, 24(2), 177-190. doi.org/10.1080/14631377.2012.6 75154.

13. Solanko, L. (2008). Unequal fortunes: a note on income convergence across Russian regions. Post-Communist Economies, 20(3), 287-301. https://doi.org/10.1080/14631370802281399.

14. Ledyaeva, S., \& Linden, M. (2008). Determinants of Economic Growth: Empirical Evidence from Russian Regions. European Journal of Comparative Economics, 5(1), 87-105.

15. Kholodilin, K. A., Oshchepkov, A. \& Siliverstovs, B. (2012). The Russian regional convergence process: Where is it leading? Eastern European Economics, 50(3), 5-26. doi.org/10.2753/EEE0012-8775500301.

16. Akhmedjonov, A., Lau, M. C. K., \& İzgi, B. B. (2013). New evidence of regional income divergence in post-reform Russia. Applied Economics, 45(18), 2675-2682. doi.org/10.1080/00036846.2012.665600.

17. Lehmann, H. \& Silvagni, M. G. (2013). Is There Convergence of Russia's Regions? Exploring the Empirical Evidence: 1995-2010. IZA Discussion Papers, 7603. Retrieved from: http://dx.doi.org/10.2139/ssrn.2321098 (date of access: 02.10.2018).

18. Dolinskaya, I. (2002). Transition and Regional Inequality in Russia: Reorganization or Procrastination? IMF Working Paper, 2, 169.

19. Demidova, O. \& Signorelli, M. (2012). Determinants of Youth Unemployment in Russian Regions. Post-Communist Economies, 2, 191-217. doi.org/10.1080/14631377.2012.675155.

20. Demidova, O., Marelli, E. \& Signorelli, M. (2013). Spatial Effects on Youth Unemployment Rate: The Case of Eastern and Western Russian Regions. Eastern European Economics, 5, 94-124. doi.org/10.2753/EEE0012-8775510504.

21. Demidova, O., Marelli, E. \& Signorelli, M. (2015). Youth Labor Market Performance in the Russian and Italian Region. Economic Systems, 39(1), 43-58. doi.org/10.1016/j.ecosys.2014.06.003.

22. Blinova, T., Markov, V. \& Rusanovskiy, V. (2015). Youth unemployment in Russia: Models of interregional differentiation. Regional Formation and Development Studies, 15(1), 7-18. http://dx.doi.org/10.15181/rfds.v15i1.975.

23. Blinova, T., Markov, V., \& Rusanovskiy, V. (2016). Empirical study of spatial differentiation of youth unemployment in Russia. Acta Oeconomica, 66(3), 507-526. doi.org/10.1556/032.2016.66.3.7.

24. Rusanovskiy, V. \& Markov, V. (2016). Youth unemployment in Russian Regions and assessment of the economic loss. Indian Journal of Science and Technology, 9, 30. Retrieved from: http://www.indjst.org/index.php/indjst/article/view/98754 (date of access: 02.10.2018).

25. Danilenko, T., Demidova, O. \& Signorelli, M. (2017). Unemployment Clubs in Russian Regions. Emerging Markets Finance and Trade, 54(6), 1337-1357. https://doi.org/10.1080/1540496X.2017.1281799.

26. Gimpelson, V. E., Zudina, A. A., Kapelyushnikov, R. I., Lukyanova, A. L., Oschepkov, A. Yu., Roshchin, S. Yu., Smirnykh, L. I., Travkin, P. V. \& Sharunina, A. B. (2017). The Russian labor market: trends, institutions, structural changes. In: Gimpelson, V. E., Kapelyushnikov, R. I., Roshchin S. Yu. (Eds). Moscow: Center for Strategic Research. Retrieved from: https://lirt.hse.ru/data/2017/03/21/1170068107/Doklad_trud.pdf (date of access: 02.10.2018). (In Russ.) 
27. Arellano, M. \& Bond, S. (1991). Reviewed Some Tests of Specification for Panel Data: Monte Carlo Evidence and an Application to Employment Equations. The Review of Economic Studies, 58(2), 277-297.

28. Lee, L. F. \& Yu, J. (2010). Estimation of spatial autoregressive panel data models with fixed effects. Journal of Econometrics, 154(2), 165-185. doi.org/10.1016/j.jeconom.2009.08.001https://s100.copyright.com/ AppDispatchServlet?publisherName=ELS\&contentID=S030440760900178X\&orderBeanReset $=$ true.

29. Greene, W. H. (2012). Econometric analysis, 7th ed. Upper Saddle River, NJ: Prentice Hall. 1188.

30. Crowley, S. (2016) Monotowns and the political economy of industrial restructuring in Russia. Post-Soviet Affairs, 32:5, 397-422. doi.org/10.1080/1060586X.2015.1054103.

\section{Authors}

Olga Anatolyevna Demidova — PhD in Mathematics, Associate Professor, National Research University Higher School of Economics; Author Scopus ID: 6602926736 (26, Shabolovka St., Moscow, 119049, Russian Federation; e-mail: demidova@ hse.ru).

Pierluigi Daddi - Professor, Department of Economics, University of Perugia; Author Scopus ID: 55832980300 (Via A. Pascoli, 20, 06123, Perugia, Italy; e-mail: pierluigi.daddi@libero.it).

Ekaterina Vladimirovna Medvedeva — Leading Specialist, PJSC “Post Bank” (32/1, Kutuzovsky Ave., Moscow, 121165, Russian Federation; e-mail: medvedevaekvl@yandex.ru).

Marcello Signorelli - Professor, Department of Economics, University of Perugia; Author Scopus ID: 24774145900 (Via A. Pascoli, 20 06123, Perugia, Italy; e-mail: marcello.signorelli@unipg.it). 